\title{
The Profession
}

\section{Where Do You Get Your Ideas?}

\author{
Nelson W. Polsby, University of California at Berkeley
}

\author{
Editor's Note: This article was given \\ as a speech on May 1, 1992, at the \\ centennial of the University of \\ Chicago.
}

The subject of this symposium is so vast and so interesting I have had some difficulty deciding how to focus my own contribution. Something about the atmosphere of this wonderful university encourages visitors to want to exhibit particularly good behavior and to put forward their most seriously thought-through ideas. Otherwise, we would not be living up to the great expectations that Charles Merriam, Robert Park, Louis Wirth, Frank Knight, and Robert Redfield have bequeathed to many of you here today.

It has occurred to me that your Dean has shown imagination of exactly the sort one would associate with the University of Chicago in asking for a contribution to a symposium on social science and public policy from somebody who, like me, has never put a hand to executing any public policy and never has had the slightest influence on public policy, but who is, or tries to be, a close observer-maybe even a systematic observer-of policy making and sometimes an explainer of these rather complicated processes as they occur, mostly, in the context of American national government. And so what I will try to do today is to talk about research that I have done, or seen, that has in some way been relevant to American public life, and perhaps, along the way, draw a few lessons that might help others to be more alert watchers of these processes.

As a subscriber to the belief best expressed by my California colleague, Ray Wolfinger, that the plural of anecdote is data, I will begin with a tribute to one of the inspirations of my youth, Senator Joe McCarthy. I lived in one of the suburbs of Washington, D.C., during the early 1950s, when Joseph McCarthy and his allegations about the communist sympathies of various Americans were very much in the headlines. Into the home of my parents came people who hated and feared McCarthy and didn't like what he was doing to disturb the peace and decency of the Washington community. His influence, they believed, was enormous, and his popularity such that all elected officials everywhere-and certainly in the U.S. Senate-had to give him a wide berth and-at a minimum-be deferential to the sentiments he was expressing.

I remember the utter disbelief of the Washington audience when Samuel Stouffer came to town and outlined the findings of what to my teenage eyes seemed-and I will confess to you today still seems-a perfectly beautiful piece of research later published in a book called Commumism, Conformity and Civil Liberties (1955). This study showed a lot of interesting things. A small piece of it demonstrated that McCarthy didn't have the attention of the American people and that domestic communism was of minuscule concern to them. McCarthy was a paper tiger. Washington elites were turning themselves inside out to accommodate a thug whom they knew perfectly well to be a pathetic charlatan because in those far-off days they didn't understand very much about the dynamics of public opinion. Flying by the seat of their pants, Washingtonians were spooking one another into pusillanimous behavior that grievously damaged our foreign policy establishment and our international information effort and ruined and shortened some lives needlessly.

Or, at least, so I thought. And I wondered if it was possible to do better. It occurred to me at the time that there might be ways of adjudicating between the varied beliefs of political leaders that served as factual premises for some of their public acts. My first more or less independent work as a social scientist was to look further into the grassroots popularity of Joe McCarthy. This meant, for an undergraduate student, mostly tracking down published information about McCarthy-polls, local studies, M.A. and Ph.D. theses by such future luminaries as Martin Trow and Immanuel Wallerstein, and election statistics in races where McCarthy was thought to be a factor.

It was really a lot of fun, because on the whole it showed that Samuel Stouffer was right and Washington elites were wrong about McCarthy (see Polsby 1960). Not only was the work fun, but trying to get things right was fun. The general activity of seeking to firm up, or discredit, the factual premises on which social and political action are based seemed to me to be a socially worthwhile activity. It still does, and one of the great mysteries to me is why in advanced societies the social investment is so modest in trying to establish on a firmer footing the factual premises of social and political action. I will return to this theme in a moment.

First, however, I want to talk about another episode that resembles the McCarthy anecdote in some respects. It happened in early 1966, about 10 years after McCarthy had gone to his reward. American involvement in the Vietnam war was beginning to cause acute social distress at home, more or less as pre- 
dicted by scholars who knew something about the responses of mass publics to limited war.

President Johnson had declared a moratorium on bombing in Vietnam over Christmas 1965 , but early in 1966, seeing no progress toward a favorable resolution of the conflict by diplomatic means, he decided to start the bombing again. This agitated many people in the academic community, who had already invented the teach-in, and had begun to show other signs of strong opposition to our vigorous prosecution of the war. President Johnson made the claim at that time that, given the dispositions of the opinions of the American people, he had no real option but to forge ahead. And, indeed, Gallup polls and other published polls showed numbers like $61 \%$ of American adults backing the president and, presumably, the war.

At that time, I was at the Center for Advanced Study in the Behavioral Sciences, an idyllic think tank that sits on a hill overlooking the Stanford campus. Among my friends and colleagues at Stanford were some shrewd students of public opinion-notably Sidney Verba and Dick Brody of the Stanford political science department, and also a gifted young graduate student named Norman Nie.

Like many people who were reading the newspapers, we felt extremely uncomfortable with the way our Vietnam policy was going, but for one reason or another it did not appeal to us to express that discomfort through the mass meetings, or marches, or manifestations of civil disorder that were common at that time. We wondered if we might not make a better contribution by turning our professional skills to at least one of the pillars that the president told us was propping up his policy, namely the alleged bellicosity of the American people.

And so we did what we had been trained to do, and put together a rather elaborate public opinion poll. Most people do not realize how thin and insubstantial the instrumentation is that undergirds most of the day-today monitoring of public opinion in this country. Typically, a question or two on politics is inserted into surveys that are paid for by commercial clients in search of marketing information. The political results are extracted and sold separately by the polling firm, usually to subscribing newspapers. By constructing a rather lengthy questionnaire exclusively devoted to uncovering the structure of public attitudes toward the war, we were creating an instrument that had the potential to improve vastly our understanding about the real constraints that public sentiment would put on the president's actions.

The poll was conducted by NORC, the National Opinion Research Center, here in Chicago, and was paid for in part by voluntary contributions from the Stanford community, and in part through the generosity of NORC. And, I must say, it was a rather good piece of work.

For one thing, some of the questions tracked the commercial polls, in order to make sure that we understood the relations between our more elaborate results and the results they were getting. And, indeed, our findings about support for President Johnson were just like the Gallup and Harris poll findings. We went further, however, and constructed two scales, one tapping sentiment favoring escalation of the conflict, one asking about de-escalation. And we also asked about the public's willingness to bear costs of the conflict at increased, decreased, and more or less the same levels of investment.

What we found, underneath all that support for the president, was an American people more ready to de-escalate than to escalate and showing glimmerings of concern about the costs of the war. We issued a copy of a press release on our findings giving full details, an analysis of the questionnaire, and the questionnaire verbatim. The story made the front page of the New York Times, because of course our results showed that the public opinion rationale that President Johnson was peddling to the newspapers was basically unfounded.

In the ensuing couple of weeks, two interesting things happened. At first, we had to endure some stiff ad hominem criticisms from friends of the president in the national press corps-notably Phil Potter of the Baltimore Sun, Tom Wicker of the New York Times, and the syndicated columnists Evans and Novak. The latter refused us access to their list of client newspapers when we wrote a rebuttal to some of their less tenable accusations and tried to circulate the response to the same papers that had published their column. The second thing that happened was that the commercial polls beefed up their own questionnaires to see if we were right -and in the ensuing weeks and months began to corroborate what we had found (see Polsby 1969).

I believe we had no impact whatsoever on the prosecution of the war, but we did, it seems to me, contribute to public enlightenment in a responsible way, and we helped Americans a little to get their bearings in a troubled time.

I'd like to contrast that experience with a more recent effort meant to do much the same thing-the June 1991 report for the Kettering Foundation called Citizens and Politics, $A$ View from Main Street America, prepared by a private company called the Harwood Group of Bethesda, Maryland.

The conclusions of this report were quite sensational. In the words of the president of the Kettering Foundation:
Harwood insisted . . . that the conven- tional interpretation of the American public as overwhelmingly apathetic is dead wrong. The people we had inter- viewed in focus groups across the country weren't apathetic. They were mad as the devil about a political system they believed had spun out of their control; a system run by a pro- fessional political class of powerful lobbyists, overly incumbent politicians, and a media elite; a system in which votes no longer made any difference because money ruled; a system with its doors closed to the average citizen (Mathews 1991, 78).

This is, to put it mildly, a searing and comprehensive indictment of the American political system. Kettering got some considerable attention to this indictment, beginning with a press conference at the National Press Club in Washington, D.C. and an initial distribution of 20,000 copies of the 67-page report plus an 11-page executive summary, both printed in handy little booklets.

The president of the Foundation continues: 
The report had barely hit the wire services ... . when the calls began to flood in. . . . Extra operators had to be added just to take the requests for copies. . . . For weeks after the report was published, Richard Harwood was booked into radio talk shows. At the end of one hour-long call-in program, 1,200 callers were waiting to be heard. Over a thousand inquiries ... came from citizens organizations, political parties, members of Congress, state legislators, . . . labor unions. . . .

There have been over 1,000 stories and editorials in the United States and 9 other countries (Matthews 1991, 79).

Self-congratulation rises from these words like the morning mist over a barnyard. And it worried me. To a social scientist who cares about the subject, the first and foremost question that arises from this comprehensive indictment of the American political system issued in the name of the American people by "a small public issues research and consulting firm located in Bethesda, Maryland" and publicized by the Kettering Foundation is this: Is it true?

My view of this matter is that Kettering hasn't given us remotely enough to go on to decide this issue, and it is alarming that they are so eager to accept the verdict of radio talk shows in disposing of the matter. The findings were based on conclusions drawn from 10 focus groups convened in different places around the country between April 15, 1990, and May 15, 1991. They consisted of "approximately 12 people" each. Each of these group discussions lasted "for about two hours" and were "led by a trained moderator" and recorded. All this from a twopage methodological appendix.

Well, here's the problem: A really skilled moderator ought to be able in two short hours to get a focus group of "approximately 12 people" to say nearly anything. "Technically speaking," the methodological appendix says, the observations detailed in the report are "hypotheses or insights that would need to be validated by reliable quantitative methods before being considered definitive." My view is that they should have been.

What a pity the resources of the Kettering Foundation didn't stretch a little farther before they held their National Press Club press conference. The NORC, I'm happy to say, is still in business and might have helped them design a study that would meet elementary scientific standards. Because more than technicalities are involved. It is important substantively to know whether or not one's conclusions are justified by appropriate evidence.

The Stanford group in 1966 went out of its way to invite the judgment of the social science community by publishing in full the contents of its questionnaire, the exact word ordering of items, the sequence in which they were asked, and raw results for each and every question. This study has stood the test of time, and of peer review. Articles based on the study have been published in refereed professional journals, and so on (see, e.g., Verba et al. 1967).

The lesson here, it seems to me, is this: that social science really does have a role to play in sorting out issues of this kind, issues pertaining to the opinions and attitudes of mass publics. Social science is most certainly science in a number of respects that are highly relevant to the Kettering study. We are, for one thing, a professional community with professional norms to uphold. We can, with the cooperation of the original investigators, see if a study was done as it was claimed to have been done. We can see if known weaknesses of the methods used were adequately guarded against. We can see if other investigators, using similar or better methods, get similar results.

Not so long ago two chemists working at the University of Utah called a press conference to announce -and here I am exercising poetic license on the complicated subject of cold fusion-that they could get quite a jolt by sticking a couple of wires in a glass of water. The whole world was astounded. So was the scientific world, which went to work to see if they could incorporate the announced findings into an ongoing body of scientific knowledge. Scientists from all over asked for further details so that they could replicate the Utah cold fusion experiments. They went over the Utah measurements and instruments carefully. And so on. The current verdict is: Negative. The press conference was premature. The conclusions announced there would not stand the scrutiny of peer review.

I think it is important for the authors of those 1,000 newspaper articles on popular dissatisfaction with American politics to know that the same goes for social science: the same rules of discourse, the same community standards.

I have tried to indicate why I think it is socially important for information about social and political life to be regarded as in principle capable of being tested by high standards and incorporated into a provisionally certified body of knowledge. At a minimum, the risks of acting on false empirical premises are sometimes unacceptable.

If, in fact, American public disaffection is as deep and as widespread as the Kettering Foundation says it is, it is a wonder to me that it took 10 focus groups last year to winkle the information out of the American people. It would be a pity if influential people thought that what those focus groups allegedly concluded was true in case it isn't true. But if they thought so, I could imagine them advocating congressional term limits, let us say, or some other attack on one or another American political institution.

So the failure to invest properly in the careful evaluation of social knowledge seems to me a general problem worth thinking about. It is an agenda I would urge on more of our great foundations-not just Kettering-in part because we have good reasons to think that the government will always be laggard at best in this enterprise. And that will constitute the last part of this sermon.

I suppose one of the main satisfactions of doing political science research is that we have a professional license to put on our asbestos suits and go where the hot spots are. Wherever there is some issue in society that is hotly controverted and where emotions are strong, there ought to be-and sometimes there are-a few social scientists who are attempting to sort out what the facts can tell us.

This is a job of fundamental importance, because facts rarely speak for themselves. There are usually too many facts, and not infrequently too many different versions of the facts. Rather than speak- 
ing for themselves, various facts have what we have come to refer to as spokespersons.

Spokespersons marshall facts as premises for political and social actions of all sorts, and their fundamental loyalties run to their conclusions, not their premises. Somebody has to think about the premises, and to decide whether or not they are well founded.

I think those of us who are ordinarily not spokespersons should confess that we have had notable failures as well as some successes in this business. Some of you may have heard of the phenomenon of political correctness. This is in part about efforts within the community of scholars-usually in alliance with outsiders-to make some subjects too hot for disinterested social inquiry. At one time in our recent history, the study of factors supporting the overthrow of corrupt East Asian regimes was such a topic; later on we had to be careful about the subject of the heritability of socially valued characteristics. We have also had to think twice before discussing issues linking the racial composition of the domestic population with various forms of social disadvantage. This also became taboo. On the whole, social scientists respect these taboos. I will therefore leave to others the task of discussing the document entitled The Negro Family (U.S. Department of Labor 1965) if they care to do so. I merely ask: ought others to be abandoned in this fashion?

Anything that strengthens the capacities of professionals at social science to do their job seems to me a good idea. Their job at bottom includes not being too sure who or what is right until appropriate inquiries, meeting appropriate scientific standards, are made. Thus efforts at restricting the subjects of inquiry seem to me deplorable, and the mandarins of political correctness likewise deplorable.

In some nations, it is impossible to take a census because the results might upset a precarious political bargain based on census numbers. This particular taboo on basic social inquiry doesn't exist in the contemporary United States. The reason we should take comfort from this fact is precisely because we are ourselves not free from restrictions and attempts to restrict social inquiry. We are therefore obliged to countthat is, take a census of-our blessings.

Some years ago I attempted to find out how our political system went about the task of political innovation (Polsby 1984). I looked around and identified a bunch of episodes that seemed to me defensible as innovations: instances where the result was a long-lasting change in the repertoire of responses that our nation was making to a set of problems. The formation of the Peace Corps, the National Science Foundation, and the Council of Economic Advisors were three such examples. There were a bunch of others.

The question was, how did they start? In most cases, the stories are complicated, but it is worth mentioning that almost always the germ of the idea first occurred to a subjectmatter specialist-an expert-working in a university or a think tank or on the staff of an interest group. The knowledge or expertise that turned out to be most relevant to the process of invention was usually comparative knowledge-that is, knowledge of how some other political system or how a private sector entity addressed the same problem. American politicians on the whole haven't got the time to find out the right analogies between our uniquely complicated political systems and other uniquely complicated political systems. But because they must run for office frequently, and because they are faced on a daily basis with social problems that come to them in the course of their business, and because they believe in problem-solving, public officials frequently express a voracious demand for ideas about how to make things work a little better. And so politicians are motivated to harvest each crop of ideas that experts nurture, and to try them out by activating well-known procedures in the political system: holding hearings or making campaign speeches, for two examples.

Social science plays a part in at least two stages of the political innovation process: Right at the beginning, where ideas are hatched by experts who think about problems and about analogies to the ways in which institutions they already know about address these problems. Then, later on, the marshalling of facts and justifications in a process that looks like research may take place as advocates of an innovation attempt to put it on the agenda for enactment. It looks like research, but of course it isn't quite, because the purpose of the inquiry is to produce back-up for one side or another in a political contest over the agenda. This latter activity may be all that most political leaders see of social inquiry. It is not a good basis from which to make a case that the government should invest more in real social inquiry, where a fuller spectrum of results is possible. Social science requires the risk of failure to answer questions adequately, or the possibility that, from the standpoint of any given politician, the wrong answer will turn up.

Most politicians of my acquaintance believe their business is already risky enough. This leaves the job of fostering policy-related social inquiry mostly to universities, think tanks, and foundations.

I hope by now I have said enough to persuade at least some of you that the relations between social science and public policy in this country are rather complicated. Social science and its standards are real cultural resources and available for widespread use. Their actual uses are constrained by intellectual fashions and taboos, by the ways in which the disciplines themselves grow and change, and by the carrying capacities of our political institutions.

As to the impact of much of this on social scientists, I offer in closing a short passage from Neil Simon's wonderful play, The Odd Couple. Felix and Oscar are getting acquainted with their double dates for the evening, the Pigeon sisters:

Cecily to Felix: What field of endeavor are you engaged in?

Felix: I write the news for CBS.

Oh! Cecily says. Fascinating!

Gwendolyn: Where do you get your ideas from? 


\section{References}

Mathews, David. 1991. "After Thoughts." Kettering Review, Fall 1991: 78.

Polsby, Nelson W. 1984. Political Innovation in America: The Politics of Policy Initiation. New Haven: Yale University Press.

Polsby, Nelson W. 1969. "Political Science and the Press: Notes on Coverage of a Public Opinion Survey on the Vietnam War." Western Political Quarterly 22 (March): 47-60.
Polsby, Nelson W. 1960. "Towards an Explanation of McCarthyism." Political Studies 8 (October): 250-71.

Stouffer, Samuel. 1955. Communism, Conformity and Civil Liberties. New York: Doubleday.

U.S. Department of Labor. 1965. The Negro Family, The Case for National Action. Washington, DC: U.S. Government Printing Office.

Verba, Sidney, Richard A. Brody, Edwin B. Parker, Norman H. Nie, Nelson W. Polsby, Paul Ekman, and Gordon S. Black. 1967. "Public Opinion and the
War in Vietnam." American Political

Science Review 61 (June): 317-33.

\begin{abstract}
About the Author
Nelson W. Polsby is a professor, department of political science, and director of the Institute of Governmental Studies, University of California, Berkeley.
\end{abstract}

\title{
Tips for Writing Papers
}

\author{
Raymond E. Wolfinger, University of California, Berkeley
}

Every year I read graduate students' papers, many of which are very good. (Some of these, fewer than I would like, are submitted to journals and published.) Whether good, bad, or indifferent, the papers often have certain weaknesses. After 30 years of exhorting students about these failings, I realized that I could save a lot of time by writing down my collected maxims. And nearly 30 years of refereeing manuscripts convinces me that these suggestions are equally appropriate for journal articles and books.

If your paper requires any sort of data gathering-interviewing politicians or ordinary citizens, observing public meetings, scrutiny of documents, analysis of the mass media, whatever-make a start on this as soon as you possibly can, before getting everything just right and doing all necessary reading. At the very least, you will learn if your plans are feasible. You may also achieve a better understanding of your topic that will alter your reading plans or, perhaps, the focus of your research.

Before you begin writing, figure out what your contribution to knowledge is going to be and organize the paper accordingly. This does not mean that you must present a lengthy survey of the literature. It does mean that some place near the beginning of the paper you should say enough about the existing state of knowledge to establish the context for your own contribution and help readers understand what you will tell them that they did not know before.

Then you should say what the paper will be about, including what specific topics you are going to explore. Perhaps also you should disclose your principal conclusions. The point is that you should never leave readers confused or uncertain about where you are going next or why you are saying what you are saying. Throughout the paper there should be a clear story line to make it easy for readers to follow you from point to point.

One implication of the preceding two paragraphs is that the introductory section or chapter probably should be written last. It's always easier to introduce something when you have the clearest idea what that something is.

Some sections of a paper are easier to write than others. Unless there is a good reason not to, I recommend starting with the easy parts. This will get the show on the road, always an important consideration when there is a risk of writer's block. (And who among us does not suffer from this ailment at least some of the time?) It will also build your confidence about the value of what you have found.

When dealing with topics that touch on the controversial, in either the scholarly or political sense, always ask yourself if it is necessary to engage in the controversy. If the controversy is essential to what you want to say, then plunge in. Your contribution will be clear, and the experience can be satisfying if not downright enjoyable. But if you can make your point without starting a fight, by all means do so. The reason is simple: You should avoid distracting readers or antagonizing them unnecessarily; you are likely to get greater acceptance from people with whom you have not picked a fight.

\section{Papers with Quantitative Data}

Begin some part of the data analysis at your earliest convenience, if possible, before doing all the background reading. This is less essential if you know for a fact that the data set you want is immediately available in the form in which you will analyze it, that you know how to do that analysis, and that you will not make any mistakes in preliminary steps like coding or recoding the data to fit your analysis plans. Nothing is more damaging to inner peace and efficient scholarship than a nasty surprise about any of these points three weeks before the end of the semester.

When beginning to analyze your data, you will note how many cases you have. Doubtless many of your data runs will be based on fewer cases for various good reasons; perhaps respondents who failed to answer or had no opinion. But be sure you know where all your cases are. Whenever you have less than the number of cases you started with, be able to account for the missing ones. If you think this advice is unneces- 